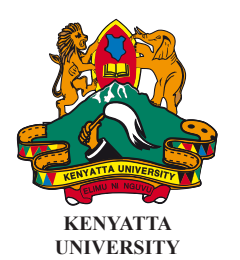

ISSN 1563-1028
CHEMCHEMI

International Journal of Humanities and Social Sciences

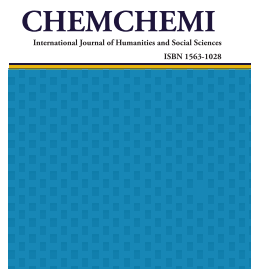

Volume 10 Number 2, 2016

OPEN ACCESS

\title{
TRANSLATION OF KINSHIP TERMINOLOGY IN SELECTED BILINGUAL DICTIONARIES IN KENYA AND ITS IMPLICATION FOR CROSS - CULTURAL COMMUNICATION
}

\begin{abstract}
Kinship terms are culturally and socially tied to the society's structure and communities' values that have developed over a long period of time. In the different Kenyan social environments many kinship terms abound that are extremely definite and cannot be found in other Kenyan languages or English and consequently may generate some translation difficulties and misinterpretations. The intended meaning of these culturally bound kinship terms that exist in source languages which are embedded in the Kenyan socio-cultural scene cannot be transferred to the target language (English) through a word or group of words which are thought to be the English equivalents in the translation process. The paper presents a list of common kinship terms present in three Kenyan languages with comparable interpretation. Kinship terms that are mainly culture specific certainly indicates the firm and close social ties that a community has established over the years. The present paper seeks to answer two main questions: i) How are the non-equivalences of kinship terms between English and the selected languages translated in different bilingual dictionaries? ii) What is the alternative model of translating kinship terms in the selected bilingual dictionaries? These kinship terms pose difficulties and intercultural miscommunication when not properly interpreted. The present paper is based on Baker's (2006) effected translation equivalence theory of Kinship terms and social structure model and equivalence theory of translation. The paper develops a model for translating kinship terms from the selected languages into English.

Key words: Kinship terminology, culture, cross-cultural communication, kinship terms, bilingual dictionary.

\section{Introduction}

The objective of this paper is to put forward approaches for the treatment of kinship terms in bilingual dictionaries with English as the source language and two Bantu languages and a Nilotic language as the target languages. English-Ekegusii dictionary by Bosire and Machogu (2009); Lulogooli-English dictionary by Ndanyi (2005) and two Dholuo-English dictionaries by Capen (1998) and Odaga (2010) will be taken as cases in point. Ekegusii is a Bantu language spoken by the Abagusi is classified as zone $\mathrm{E}$ group 42 together with Kuria by Guthrie (1948). Lulogooli is a Bantu language that is classified as zone E group 41 by Guthrie (1948) and is spoken by the Maragoli. Dholuo is classified as a Western Nilotic language that is a sub-branch of the Sudanic family of the Chari-Nile of the Nilo-Saharan unit of African languages (Greenberg, 1970). The Western Nilotic phylum is composed of languages such as Acholi, Langi, Alur, Padhola etc. of Uganda and Shilluk, Annak, Nuer, etc. of Sudan.

The present paper is in three sections. The first section compares the kinships terminology structures of English with Ekegusii, Lulogooli and Dholuo. A comparative approach would yield some language
\end{abstract}

Joyce I. Wangia and Gerry Ayieko 
universal as well as language specific aspects of kinship terms which has so far been ignored especially in the East African context. The language policy in Kenyan education system is that the first three years of learning is conducted in Mother Tongue or the language of the catchment area while English is taught as subject and from thence, English is used the medium of instruction. Bilingual dictionaries play a critical learning in the language teaching-learning process for both the learners and teachers of the different languages. The role of bilingual dictionaries in assisting second language learners comprehend the new language they are learning and facilitate cross-cultural communication cannot be ignored. One of the first concepts that children learn as they go to school is the family and kin ships terms in this case in two different languages: English which is a second language and the different mother tongues. The process of language learning involves the passing of values and attitude that are closely tied to how kinship terms are configured.

The second section evaluates the treatment of Kinship terms in the selected bilingual dictionaries. A conceptual analysis approach is adopted for purposes of counterchecking and cross-referencing of the core kinship term in each category under investigation in the three languages under investigation. This enabled the researchers to establish the core features of a kinship term and the associated lexemes. Conceptual analysis helps to establish the degree of equivalence and allow for the assessment of congruence and acceptability of the kin term lexemes in question. The present paper suggests that Nida's functional equivalence theory can be incorporated in the process of lemmatization of Kinship terms in bilingual dictionaries. The third section proposes a new alternative paradigm of treating Kinship terms in the said dictionaries.

\section{Methodology}

The data for the present paper was collected using the survey method. Questionnaires were sent to different competent speakers of the three languages between December 1 and 31, 2014.

\section{Population and Sample}

The population of the present study according to the 2009 Kenya Population and Household Census was as follows: Dholuo spoken in Migori dictrict was 335,873, Luloogoli spoken in Vihiga district 221,294 and Ekegusii spoken in Kisii central 365,745. However a sample was selected of thirty speakers each and questionnaires were administered that required them to fill in the different kinship terms in their respective languages. This sample was considered adequate based on the homogeneity of the speech community. The second consideration that made the researchers settle for that number is the unit of analysis was not individual speakers but specific word equivalence.

\section{Survey Instrument}

The researchers developed a comprehensive word list that had the terms that they were interested in investigating their equivalents in English. The entire list is presented in the format of different generations in English. The responses that were generated in the word list were compared with what is presented in the different dictionaries.

\section{Ethical Consideration}

The study took care of the privacy of the respondents and anonymity by focusing on the responses and not the respondents as well as explaining the purpose of the study and allowing them the option to pull out.

\section{Equivalence and Translation of Kinship Terms from English into African Languages}

Each language has its own unique kinship words that define the precise sets of relationships and are 
lexicalized differently from one language to another. Discussing kinship terms from the point of view of Eskimo Kinship

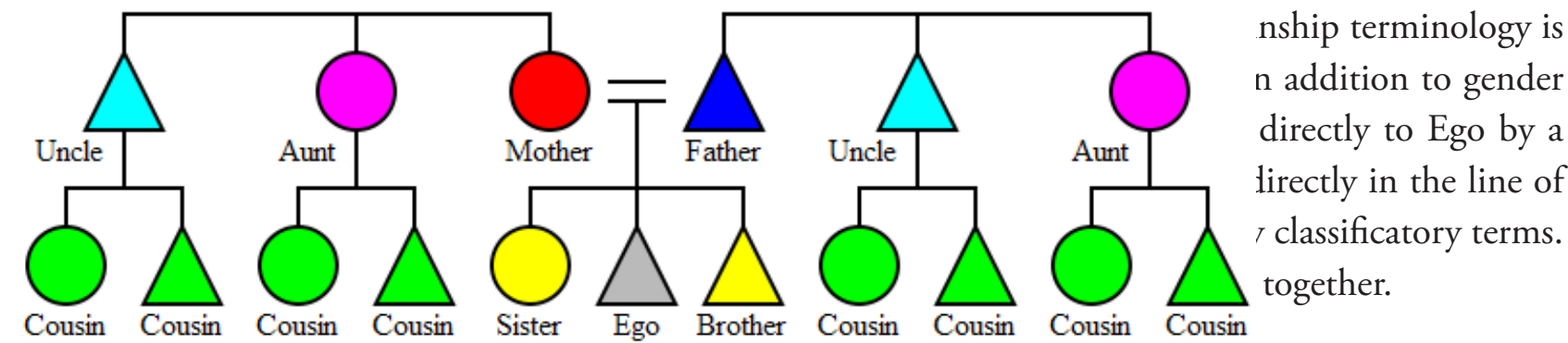

Source: Google image

The English kinship system is characterized by three things. The first is that it is bilateral in that there is no distinction between Ego's father's relative and Ego's mother's relative. Second, there are distinctions that mark differences sex, generation, and collateral kinship distance. Finally each family relationship is assigned a distinct term, more distant relatives are grouped together. In English there are twelve main kin terms as shown below:

Table 1: The Main Kinship Terms in English

\begin{tabular}{|l|l|}
\hline Kin term & Kin type \\
\hline Father & F \\
\hline Mother & B \\
\hline Uncle & FB,MB \\
\hline Brother & B \\
\hline Cousin & FBS,FBD,FZS,FZD,MBD,MZS,FFBSS etc \\
\hline Son & S \\
\hline Nephew & BS,ZS \\
\hline Aunt & FZ,MZ \\
\hline Sister & Z \\
\hline Daughter & D \\
\hline Niece & BD, brother's daughter ZS sister's daughter \\
\hline &
\end{tabular}

Ekegusii and Lulogoli are Bantu languages which have the Iroquios kinship type following Murdoch (1949) taxonomy. The system is characterized by classificatory and descriptive terms based on gender and generation as well as distinguishing between siblings of opposite sexes in the parental generation. A genealogical relationship traced through a pair of siblings of the same sex is classed as a blood relationship, but one traced though a pair of siblings of the opposite sex can be considered an in-law relationship. Siblings are grouped together with parallel cousins, while separate terms are used for cross-cousins. Also, one calls one's mother's sister "mother" and one's father's brother "father". However, one refers to one's mother's brother and one's father's sister by separate terms. In Kswahili, for example, the terms mjomba and shangazi are the terms for father-in-law and mother-in-law, since cross-cousins can be preferential marriage partners. 


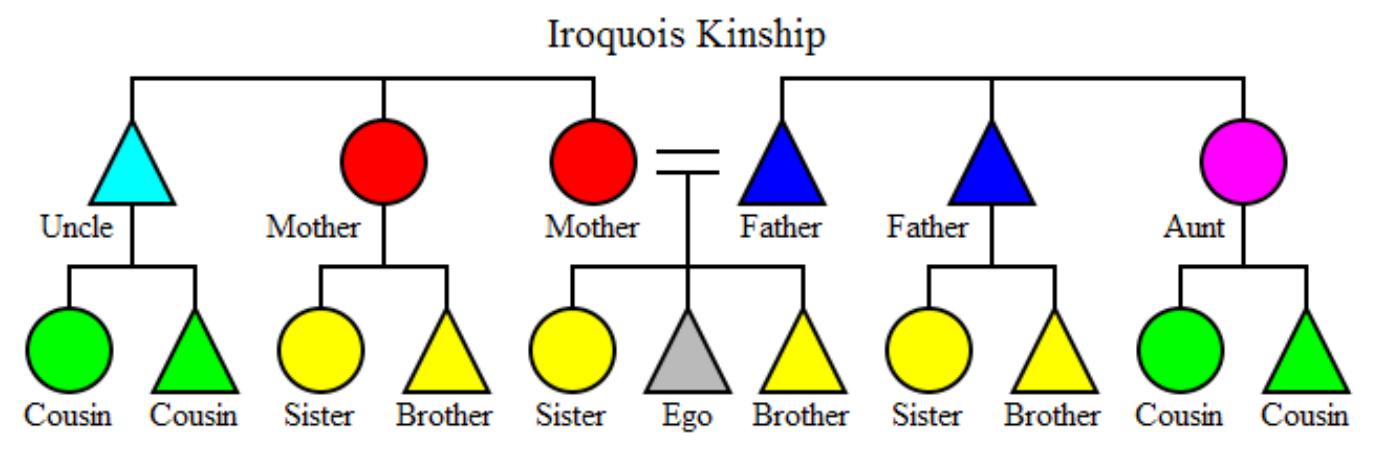

Source: Google image

Dholuo's kinship, according to Murdoch (1949), is more of the Sudanic kinship type although it doesn't fit in quite well. This system is the most descriptive. There are no two types of relatives who share the same term. Siblings are distinguished from cousins, and different terms are used for each type of cousin. There are separate terms for the following: father's brother's children, father's sister's children, mother's sister's children and mother's brother's children.

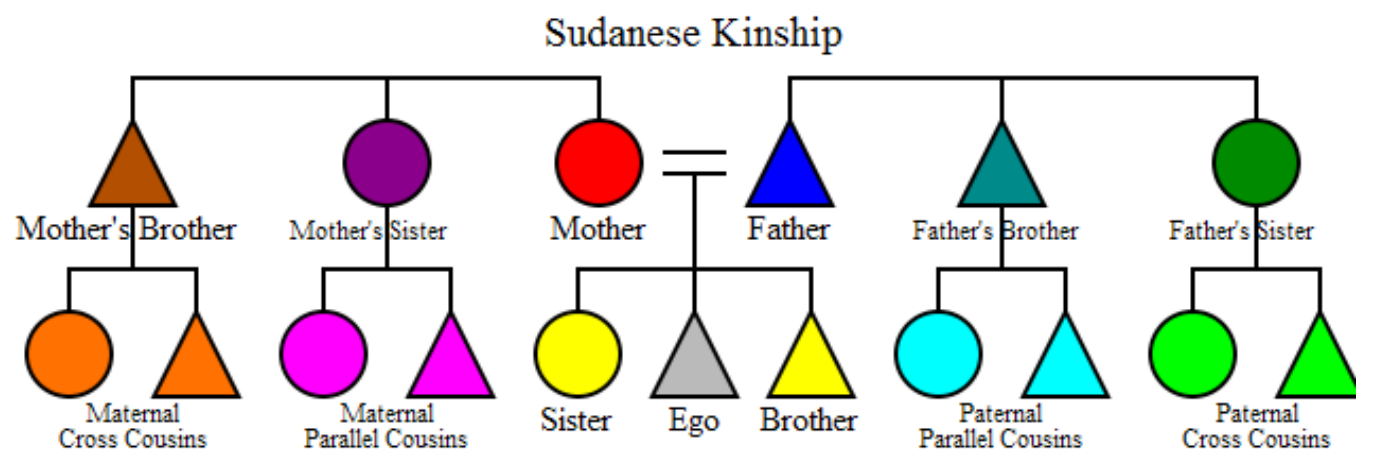

Source: Google image

One of the key objectives of the lexicographers of a bilingual dictionary is the mapping and matching of the lexical units of the source language with those units of the target language which are equivalent in their lexical meaning. This section evaluates how different lexicographers provide all potential kinship equivalents for the appropriate English entry words in the dictionaries under review. The reason why equivalence of kinship terms is important is because this is one of the first concepts second language learners master and is key to cross-cultural communication.

The current existing English bilingual dictionaries take the kinship terms for granted and do not delve much into establishing whether the meaning of the kinship term being translated is clear, accurate and natural in the target language. According to Nida (1982) Functional equivalence theory is predicated on three aspects: first the notion of equivalence, second the notion of receptors response and finally the notion of diversity.

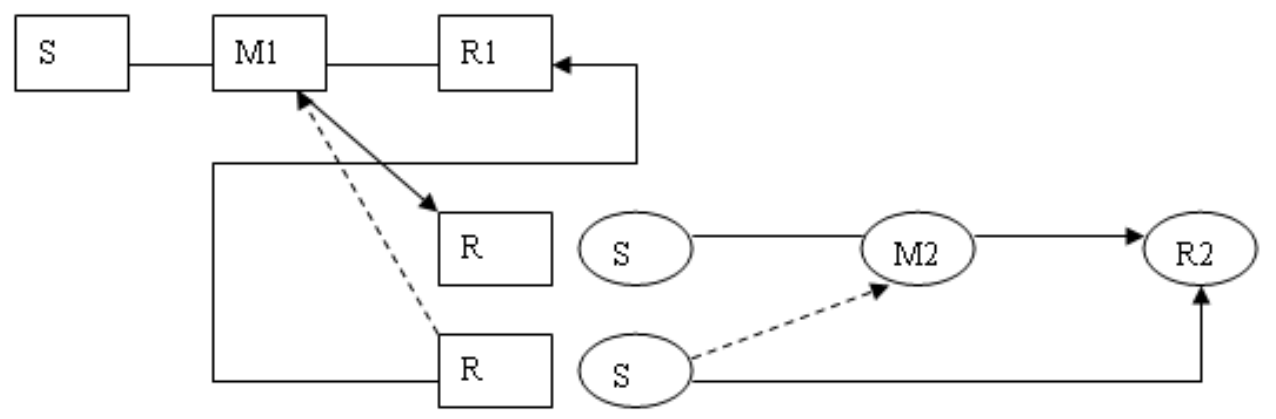

Figure 1: Conceptual Framework of Functional Equivalence Theory

Source: Nida (1982, p. 22) 
The first box represents the source (S), who sends the message (M1), which is received by an original receptor (R1). The translator, who is both receptor and source, first receives $M 1$, as if he were an 2 , and then produces in a totally different historical-cultural context a new message M2, which he wants to be understood by the final receptor R2. The differences between the two languages and the two cultural settings are represented by the different shapes. The squares represent the source-language factors and the circles represent the receptor-language factors.

\section{Equivalence and Kinship Terminology in Ekegusii-English Bilingual Dictionary}

Baker (1992) notes kinship terminology varies from one language to another and that in some cases, providing the actual meaning and correct equivalents of kinship terms is difficult. Languages differ in the way they express certain meanings. The target language may make more or fewer distinctions in meaning than the source language pausing significant cross-cultural communication challenges. According to McHenry (1992) kinship terminology is the classification that individuals in society used to define their relationship to each other based on descent and marriage. There is, however, a considerable amount of cross-linguistic variation from source language to target languages and the establishment of equivalence between languages is not a one-to-one straight forward relationship. The present section evaluates the treatment of kinship terminology in the English-Ekegusii dictionary by Bosire and Machogu (2009). The treatment of Kinship terms is discussed in the Ego's generation, Ego's parent's generation, Ego's grandparent's generation, Ego's children's generation, and Ego's affinal relationship.

\section{Ego's generation in Ekegusii}

English term
Sister
Sister grown up
Brother
Step- brother
Step -sister
Son of father's brother
Daughter of father's brother
Son of mother's brother
daughter of mother's brother
Son of mother's sister
Daughter of mother's sister

$\begin{array}{ll}\text { Ekegusii equivalent } & \text { Bosire and Machogu (2009) } \\ \text { Omusubati } & \text { Omusubati } \\ \text { Omusubati } & \text { Omusubati } \\ \text { Momura } & \text { Momuraominto } \\ \text { Momura } & \text { No entry } \\ \text { Omusabati } & \text { No entry } \\ \text { Bwambwabo } & \text { Bwambwabo } \\ \text { Bwambwabo } & \text { No entry } \\ \text { Bwamwabo } & \text { No entry } \\ \text { Bwamwabo } & \text { No entry } \\ \text { Bwamwabo } & \text { No entry } \\ \text { Bwamwabo } & \text { No entry }\end{array}$

Contrary to the dichotomy of Iroquois kinship system to which Ekegusii belongs where in Ego's generation the children of the father's brother should be referred to as brother and sister, momura ominto and omusabati respectively, they are referred to as bwambwabo. The children of the mother's sister's children are also referred to as brother and sister unlike in Ekegusii where they are referred to as bwamwabo. There are no entries for step-brother and step-sister which overlooks polygamy as a significant aspect of Ekegusii family reality which had significant impact on the kinship relation. Whereas the English speakers have a single term brother which means siblings born of the same father and mother in Ekegusii this term is expanded to include other relations such as son of father from a step-mother, son of father's brother and son of mother's sister. 


$\begin{array}{lll}\begin{array}{l}\text { Ego's Parent's Generation in Ekegusii } \\ \text { English term }\end{array} & \begin{array}{l}\text { Ekegusii equivalent } \\ \text { Ego's mother }\end{array} & \text { Bosire and Machogu (2009) } \\ \text { Ego's father } & \text { Baba } & \text { Baba } \\ & \begin{array}{l}\text { Tata; Omose; Iboria; } \\ \text { Omosasiroti }\end{array} & \begin{array}{l}\text { Tata; Omose; Iboria; } \\ \text { Omosasiroti }\end{array} \\ \text { Ego's father's brother } & \text { Nyokorometata-moke } & \text { Nyokorome } \\ \text { Ego's father's sister } & \text { Maka-moke } & \text { Mako-moke } \\ \text { Ego's mother's brother } & \text { Mame } & \text { Mame } \\ \text { Ego's mother's sister } & \text { Makamoke } & \text { Makamoke } \\ \text { Ego's father's brother's wife } & \text { Makomoke } & \text { No entry } \\ \text { Ego's father's sister's husband } & \text { Tatamoke } & \text { No entry } \\ \text { Ego's mother's sister's husband } & \text { Mame } & \text { No entry } \\ \text { Ego's mother's brother's wife } & \text { Makomoke } & \text { No entry }\end{array}$

There are precise lineal terms used to represent the nuclear family: tata (own father), baba (own mother), momura one (own son), and mosubatiom into (young woman of our house). The Ekegusii kinship system seems to fit into the bifurcate that differentiate clearly between the uncles on the father's side and those on the mother's side and has separate terms for each namely nyokorome for paternal uncle and mame for maternal uncles. In the English language uncle from both sides are not differentiated as seen in the Ekegusii terms nyokorome and mame which are lexicalized as uncle. The term makamoke is used to refer to two different people in the family tree.

$\begin{array}{lll}\begin{array}{l}\text { Ego's Grandparent's Generation in Ekegusii } \\ \text { English term }\end{array} & \text { Ekegusii equivalent } & \text { Bosire and Machogu (2009) } \\ \text { Ego's grandmother } & \text { Magokoro } & \text { Magokoro } \\ \text { Ego's grandfather } & \text { Sokoro } & \text { Sokoro } \\ \text { Ego's grandparents } & \text { Esokoro } & \text { Esokoro } \\ \text { Ego's grandfather's Brother } & \text { Esokoro } & \text { Esokoro } \\ \text { Ego's grandfather's sister } & \text { Magokoro } & \text { Magokoro } \\ \text { Ego's grandmother's brother } & \text { Sokoro } & \text { No entry } \\ \text { Ego's grandmother's sister } & \text { Magokoro } & \text { No entry } \\ \begin{array}{l}\text { Ego's grandfather's brother's } \\ \text { wife }\end{array} & \text { Magokoro } & \text { No entry } \\ \begin{array}{l}\text { Ego's grandfather's sister's } \\ \text { husband }\end{array} & \text { Sokoro } & \text { No entry } \\ \text { Ego's grandmother's sister's } & \text { Sokoro } & \\ \text { husband } & & \text { No entry } \\ \begin{array}{l}\text { Ego's grandmother's brother's } \\ \text { wife }\end{array} & \text { Magokoro } & \text { No entry }\end{array}$

Bosire and Machogu (2009) do not give dictionary entries for six kinship terms in Ekegusii that are significant in Ego's grandparent's generation. Those of the grandchildren's generation are omochokoro, and those of the grandparents' generation are sokoro (grandfather) and magokoro (grandmother). There are a number of missing entries in Bosire and Machogu (2009) which can be attributed to the fact that full kinship structure was not used as the basis of the lexical entries in the dictionaries. 


$\begin{array}{lll}\begin{array}{l}\text { Ego's Children's Generation in Ekegusii } \\ \text { English term }\end{array} & \begin{array}{l}\text { Ekegusii equivalent } \\ \text { Ego's male child }\end{array} & \begin{array}{l}\text { Bosire and Machogu (2009) } \\ \text { Omomura, Omwana }\end{array} \\ \text { Oneomomura } & \\ \text { Ego's female child } & \text { Owanaomoiseke } & \text { Owanaomoiseke } \\ \text { Ego's Brother's son } & \text { Omwana, omoigwa } & \text { Omwana, Omoigwa } \\ \text { Ego's brother's daughter } & \text { Omoigwa } & \text { Omoigwa } \\ \text { Ego's sister's son } & \text { Omwana,Owana } & \text { Omoigwa } \\ \text { Ego's sister's daughter } & \text { Omwana one } & \text { Omoigwa } \\ \text { Ego's child of son of uncle } & \text { Omwana one } & \text { Omoigwa } \\ \text { Ego's maternal cousin's son } & \text { Omwana one } & \text { No entry } \\ \text { Ego's maternal cousin } & \text { Omwana one } & \text { No entry } \\ \text { daughter } & & \text { No entry } \\ \text { Ego's paternal cousin child } & \text { Omwana one } & \text { No entry } \\ \text { Ego's maternal cousin child } & \text { Omwana one } & \end{array}$

All members of the descending generation are omwana one (my child) and there is no distinction that is made based on gender. For the generation directly below that of the ego, the same term omwana one is used by ego to refer to the children of his brothers and sisters and step-brother and step-sister's children, paternal cousins' children, and maternal cousins' children and they are not distinguished from one's own children. Bosire and Machogu (2009) did not take into account the parallel cousin and cross cousin relationships in their entries of kin term lexemes in Ekegusii as can be realized from the above instances that have been cited from their work.

$\begin{array}{lll}\begin{array}{l}\text { Ego's Affinal Relations in Ekegusii } \\ \text { English term }\end{array} & \begin{array}{l}\text { Ekegusii equivalent } \\ \text { Tatabiara }\end{array} & \begin{array}{l}\text { Bosire and Machogu } \\ \mathbf{2 0 0 9 )}\end{array} \\ \text { Ego's wife's father } & \text { Makobiara } \\ \text { Ego's wife's mother } & \text { Makobiara } & \begin{array}{l}\text { Makobiara } \\ \text { Ego's wife's mother's sister } \\ \text { Ego's wife's mother's brother }\end{array} \\ \text { Ego's wife's brother's wife } & \text { Kamati } & \\ \text { Egos wife's sister's husband } & \text { Semo } & \text { Kamati } \\ \end{array}$

Kamati [kama:ti] title used by one's wife and her sister(s)-in-law or her husband's female cousin. Equivalence and Kinship Terminology in Lulogooli-English Bilingual Dictionary

A typical Marogoli family known as the inyumba usually consists of a husband, one or more wives and their children since the Maragoli were predominantly polygamous before the advent of Christianity. A number of families can trace their decent back to a common ancestor form irishya which would comprise of a man's grown-up sons with their wives and children. A number of closely related urusya that share the same grazing field, stream and tilled the same land formed a second level of inyumba which also acted as the basis of defence against external aggression for the individuals concerned. Several Inyumba form the umuryango which in turn forms inyumba the sub-clan level that later merge to form the ishiri or clan. Inyumba and ishiri form the basis of Maragoli social organization and kinship system. Several inyumba 
which trace their origin to a common ancestor form umuryango (a branch). Several umuryango make up urusya (main branch) which in turn make up the inyumba at a higher level and several ishiri comprise the Maragoli nation.

Presently, according to Gwako (2014), the Maragoli people continue to be organized around the principle of patrilineal descent. Sharing with needy family and community members was esteemed as a paramount cultural virtue by the Maragoli. This spirit of compassion and reciprocity was exhibited during both informal and formal visits and during times of plenty as well as periods of shortages. Sharing extended outward from members of a household/family (inyumba/mugitsi) to more distant relatives and friends. The sharing obligation generally took the form of an animal (such as a bullock, cow, heifer, ox, goat, sheep, or chicken) or a portion of a slaughtered animal, and less frequently a quantity of grain (eleusine or sorghum). Gwako (2014) adds that failure to honor sharing obligations resulted in strained relations or disputes among the relatives concerned. When relatives were unable to reconcile on their own, the matter was taken for arbitration before the council of the magura (the clan-elders; "iguru" in the singular) or, in lesser cases, before a group of relatives on either side. Gwako (2014) concludes that during hard times such as in cases of economic, social, and political distress (for example, overdue school fees, crop failure, natural disaster such as a lightning strike, illness, or death), there was an expectation of significantly more sharing. Sharing was also expected during important celebrations (weddings, childnaming rituals, honoring the dead, circumcision, and so on). Sharing in these ways was an affirmation of kinship relations. This is a critical component in kinship since one may be referred to as uncle or aunt based on this sharing system which had nothing to do with blood or marriage ties. According to Stone (2000) kinships is the recognition of a relationship between persons based on descent or marriage. If the relationship between one person and another is considered by them to involve descent, the two are "consanguine" (blood) relatives. If the relationship has been established through marriage, it is affinal. The purpose of the paper is to investigate the translation of Lulogooli kinship terms into English with reference to the Lulogooli-English translation (dictionary) by Ndanyi (2005). Lulogooli Kinship terms can be classified into five main categories as shown below. The first category is Ego's generation which is summarized in the table below:

\section{Ego's Generation in Lulogooli}

\begin{tabular}{|c|c|c|}
\hline English term & Lulogooli equivalent & $\begin{array}{l}\text { L u logo } \\
\text { Dictionary } \\
\text { 2005) }\end{array}$ \\
\hline Sister & Omukana witu/Amwavo & Amwavo \\
\hline Sister grown up & - & - \\
\hline Brother & Amiitu & Amiitu \\
\hline Step- brother & Amiitu & Amiitu \\
\hline Step -sister & Omukana witu/Amwavo & Amwavo \\
\hline Son of father's brother & Amiitu & Amiitu \\
\hline Daughter of father's brother & Omukana witu/Amwavo & Amwavo \\
\hline Son of mother's brother & Omusiala & Omusiala \\
\hline daughter of mother's brother & Omusiala & Omusiala \\
\hline Son of mother's sister & Amiitu & Amiitu \\
\hline Daughter of mother's sister & Omukana witu/Amwavo & Amwavo \\
\hline
\end{tabular}

All male individuals in the Ego's generation are referred to as Amiitu (brother, father's brother's son, father's sister's son, mother's sister's son, and mother's brother's son), while the females are referred to as either Omukana witu or Amwavo (sister, father's brother's daughter, father's sister's daughter, mother's sister's daughter, and mother's brother' daughter) . All these entries have to be lemmatized in the bilingual 
dictionary. Translating Lulogooli kin terms into English results in 'non-congruent lexical items'. For

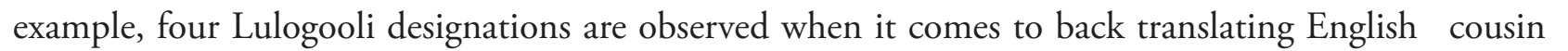
into Lulogooli as follows:

(1) the son of one's maternal uncle;

(2) the daughter of one's maternal uncle;

(3) the son of one's paternal aunt;

(4) the daughter of one's paternal aunt;

In an adequate bilingual dictionary rendition all these four different aspects of the term cousin have to be captured and lemmatized appropriately.

\begin{tabular}{|c|c|c|}
\hline \multicolumn{3}{|c|}{ Ego's parent's generation in Lulogooli } \\
\hline English term & Lulogooli equivalent & $\begin{array}{l}\text { Lulogooli-English } \\
\text { Dictionary (Ndanyi, 2005) }\end{array}$ \\
\hline Ego's mother & Mama & Mama \\
\hline Ego's father & Baba & Baba \\
\hline Ego's father's Brother & Baba & Baba \\
\hline Ego's father's sister & Senge & Senge \\
\hline Ego's mother's brother & Koza & Koza \\
\hline Ego's mother's sister & Mama & Mama \\
\hline Ego's father's Brother's wife & Mama & Mama \\
\hline Ego's father's sister's husband & Senge & Senge \\
\hline Ego's mother's sister's husband & Baba & Baba \\
\hline Ego's mother's brother's wife & Koza & Koza \\
\hline
\end{tabular}

In Ego's parent's generation, Baba refers to father and FB (father's brother), Mama refers to mother and MZ (mother's sister), Koza refers to MB (mother's brother) and Senge refers to FZ (father's sister). This is in line with the Iroquois system where the parents and their siblings share the same term. Lulogooli kinship terminology distinguishes between patrilateral and matrilateral kinship as two contrasting groups as can be seen in the table above. This is in sharp contrast to the English language where maternal and paternal relatives are not referred to by different terms and as such a translation from either of the languages has to take care of this social linguistic reality. A father is called Baba and a mother Mama in Lulogooli. The same terms apply to a father's brothers and a mother's sisters. The husband of a father's sister is referred to as Senge, and the wife of a father's brother is referred to as Mama. This also shows the kinship relation amongst the Maragoli in that the wife of the father's brother has the potential of being the mother of ego through wife inheritance when either the father of ego dies or the brother to ego's father dies. The brother of the mother, however, belongs to a different clan and this explains the use of a different term much as they belong to the same generation with ego's parents.

The Maragoli kinship is a unilineal bifurcate merging where father's brother and father are merged in a single term, $B a b a$, and distinguished from mother's brother, Koza, and mothers sister is merged with mother, mama, and distinguished from father's sister, Senge. In most cases, a kinship term in English has two or more equivalents in Lulogooli, however, Ndanyi (2005) does not reflect all or most of the aspects of meaning. In a number of instances only one equivalent is presented and this may not be very accurate to the user of the dictionary since not all aspects of the meaning are covered. Kinship is an integral part of culture and the translator has to take cognisance of this fact as they render terms form the source language to the target language. Prinsloo and de Schryver (2002) point out that an equivalent word is one which 
corresponds in meaning to a word or phrase in another language. In English, the term aunt refers to the sister of one's mother or father, and the wife of one's uncle. Conversely, in Lulogooli, aunt is used to denote a sister of one's father only, and she is called Senge and the wife to mother's brother Koza. A sister of one's mother is called Mama.

$\begin{array}{lll}\begin{array}{l}\text { Ego's Grandparent's Generation in Lulogooli } \\ \text { English term }\end{array} & \begin{array}{l}\text { Lulogooli } \\ \text { equivalent }\end{array} & \begin{array}{l}\text { Lulogooli-English } \\ \text { Dictionary (Ndanyi, } \\ \text { 2005) } \\ \text { Guku }\end{array} \\ \begin{array}{l}\text { Ego's grandmother } \\ \text { Ego's grandfather }\end{array} & \text { Guku } & \text { Guga } \\ \text { Ego's grandparents } & \text { Guga } & \text { Guga } \\ \text { Ego's grandfather's Brother } & \text { Guku } & \text { Guku } \\ \text { Ego's grandfather's sister } & \text { Guga } & \text { Guga } \\ \text { Ego's grandmother's brother } & \text { Guku } & \text { Guku } \\ \text { Ego's grandmother's sister } & \text { Guku } & \text { Guku } \\ \text { Ego's grandfather's brother's wife } & \text { Senge } & \text { Senge } \\ \text { Ego's grandfather's sister's husband } & \text { Guku } & \text { Guku } \\ \text { Ego's grandmother's sister's husband } & \text { Koza } & \text { Koza } \\ \text { Ego's grandmother's brother's wife } & & \end{array}$

The term grandfather and grandmother in Lulogooli refer to ego's grandparents as well as their brothers and sister and spouses. The English terms grandfather and great uncle are merged into one term grandfather in Lulogooli as well as the term grandmother and great aunt is merged. This requires that the complier of bilingual dictionary takes into account all these so that they render the terms from the source language in a manner that is as accurate and as clear as possible.

$\begin{array}{lll}\begin{array}{l}\text { Ego's Children's Generation in Lulogooli } \\ \text { English term }\end{array} & \begin{array}{c}\text { Lulogooli equivalent } \\ \text { Oulogooli-English } \\ \text { Dictionary (Ndanyi, 2005) }\end{array} \\ \text { Ego's male child } & \text { Omuyayi } & \text { Omuyayi } \\ \text { Ego's female child } & \text { Omukana } & \text { Omukana } \\ \text { Ego's brother's son } & \text { Omuyayi } & \text { Omuyayi } \\ \text { Ego's brother's daughter } & \text { Omukana } & \text { Omukana } \\ \text { Ego's sister's son } & \text { Omwifwa } & \text { Omwifwa } \\ \text { Ego's sister's daughter } & \text { Omwifwa } & \text { Omwifwa } \\ \text { Ego's paternal cousin's son } & \text { Omuyayi } & \text { No entry } \\ \text { Ego's paternal cousin's daughter } & \text { Omukana } & \text { No entry } \\ \text { Ego's maternal cousin's son } & \text { Omuyayi } & \text { No entry } \\ \text { Ego's maternal cousin's daughter } & \text { Omuyayi } & \text { No entry }\end{array}$

Lulogooli kin term for Ego's children for the generation are Omuyayi (boy) for all the males which includes Ego's male child, brother's son, and both paternal and maternal cousins' sons. The term Omukana (girl) includes Ego's daughter, brother's daughter, as well as the paternal and maternal cousins' daughters. The gender of the parents seems not to have a bearing on the term that will be used to refer to the child. The 
entries in the bilingual dictionaries have to capture all these realities as entries are made so as to avoid ambiguity and minimize misrepresentation of concepts.

$\begin{array}{lll}\begin{array}{l}\text { Ego's Affinal Relations in Lulogooli } \\ \text { English term }\end{array} & \begin{array}{l}\text { Lulogooli equivalent } \\ \text { Eulogooli-English Dictionary } \\ \text { Ego's wife's father }\end{array} & \text { Baba } \\ \text { Ego's wife's mother } & \text { Mama } & \text { Baba } \\ \text { Ego's wife's brother's wife } & \text { Mulamwa } & \text { Mama } \\ \text { Egos wife's sister's husband } & \text { Vasegwa } & \text { Mulamwa } \\ \text { Husband's mothers } & \text { Mama } & \text { Vasegwa } \\ \text { Husband's father } & \text { Baba } & \text { Mama } \\ \end{array}$

The fact that the same terms used in reference to ego's parents extend to the parents-in-law shows that they are expected to relate with them in the same way they relate to ego's parents. There is an expanded circle of relations and ego is expected to know how to relate to all of them in an appropriate manner. To both the woman and the man, their respective siblings are Mulamwa, brother or sister in-law; and their parents are Baba and mama, for father- or mother-in-law respectively. As for the grandparents of each side, the kin term Guga and Guku are used for wife's grandfather and grandmother respectively regardless of the whether they are maternal or paternal. The Lulogooli in-law relationships are a slight variation of consanguine relations. According to Kabaji (2005) the Lulogooli relationship, however, is based on social distance and mutual respect as exemplified by a large number of taboos that govern the in-law relationship. A bilingual dictionary should be able to capture all these different aspects of meaning.

\section{Equivalence and Kinship Terminology in Dholuo -English Bilingual Dictionary}

The present study evaluated the treatment of kinship terms in two Dholuo Bilingual dictionaries: DholuoEnglish dictionary Kenya by Capen (1998) and English-Dholuo dictionary by Odaga (2010). Dholuo belongs to the Sudanese kinship system that maintains a separate designation for each of Ego's kin based on their distance from the Ego, their relation and gender. The resulting kin system is quite descriptive and there are eight potential terms.

\section{Ego's Generation in Dholuo}

$\begin{array}{llll}\text { English term } & \text { Dholuo equivalent } & \text { Capen (1998) } & \text { Odaga (2010) } \\ \text { Sister } & \text { Nyar min } & \begin{array}{l}\text { Nyaminhiehie (Nyar } \\ \text { mama) }\end{array} & \text { Nyamin } \\ \text { Sister older } & \text { Nyarminwa maduong } & \text { No entry } & \text { No entry } \\ \text { Sister younger } & \text { Nyarminwa matin } & \text { No entry } & \text { No entry } \\ \text { Brother } & \text { Omin } & \text { Omin, owadwa } & \text { Owadging'ato } \\ \text { Brother older } & \text { Ominwa maduong } & \text { No entry } & \text { No entry } \\ \text { Brother yonger } & \text { Ominwa matin } & \text { No entry } & \text { No entry } \\ \text { Step- brother } & \text { Woud wuora } & \text { Woudwuora } & \text { No entry } \\ \text { Step }- \text { sister } & \text { Nyar wuora } & \text { Nyarwuora } & \text { No entry }\end{array}$




$\begin{array}{llll}\begin{array}{l}\text { Son of father's brother } \\ \begin{array}{l}\text { Daughter of father's } \\ \text { brother }\end{array}\end{array} & \text { Woud wuora } & \text { Wuodwoura } & \text { No entry } \\ \begin{array}{l}\text { Son of mother's brother } \\ \text { daughter of mother's } \\ \text { brother }\end{array} & \text { Woud near } & \text { Nyar near } & \text { Woudnera } \\ \begin{array}{l}\text { Son of mother's sister } \\ \text { Doughter of mother's }\end{array} & \begin{array}{l}\text { Noud minwa mar } \\ \text { minasi } \\ \text { Nyar minwa mar } \\ \text { minasi }\end{array} & \text { Woud min } & \text { No entry } \\ & \text { Nyar min } & \text { No entry } \\ \end{array}$

In the relationship between ego and his brothers and sisters and step-brothers and step-sisters the critical factor is seniority or duong vs. juniority or tin which carries with it a lot privileges as well as responsibility for each of the persons involved. For example, a junior brother, step-brother or cousin can inherit a senior brother's wife and not the reverse should the senior die before the younger. The term min nasi means Dholuo mothers are sister and this is an important distinction in Dholuo since the distinction between mother's side and father's side is very significant.

There are four different Dholuo cousin terms in Ego's generation which are distinguished from Ego's brothers and sisters which is in contrast to the English word cousin which neither distinguishes the sex nor side of the family that the relative is from. In Dholuo nyar nera denotes maternal uncle's daughter which is distinguished from nyar min paternal uncle's daughter and wuod nera maternal uncle's son and woud wuora paternal uncle's son who are all referred to as cousin. The term used to refer to daughter of paternal uncle, maternal uncle and biological sister is the same nya min which denotes that the relationship between this set of relative is quite distinct from the rest. The maternal aunt is a potential mother to the Ego just like the paternal father uncle is a potential father to the Ego. This fact is not captured in the English Kinship terminology and can cause serious cross-cultural challenges in communication and translation. Capen (1998) has provided most of the entries in Ego's generation. Odaga (2010) misses out on a number significant kinship terms in Ego's generation.

Christie, Jr. (1983) points out that the kinship terms of Dholuo show morphologically plural forms for both singular and plural possessors. This feature is not uniform throughout the system, but is present in some terms, absent in others, and variable in still others. Kinship terms in Dholuo fall into six classes according to their patterns with the pronominal possessive suffixes:

The first class, the largest, consists of those terms that have the wuod- 'son', nyar (with an inserted -n-)- 'daughter', chieg- 'wife', mikeyini- 'first wives' and chuor- 'husband' included in this class, as do the non-kinship terms.

$\begin{array}{llll} & \text { Singular } & \text { 'gloss' } & \text { Plural } \\ \text { i) } & \text { wuoda } & \text { 'my son' } & \text { wuodwa } \\ \text { ii) } & \text { wuodi } & \text { 'your son'wuodu } \\ \text { iii) } & \text { wuode } & \text { 'his son' } & \text { wuodgi }\end{array}$

The kinship terms in this generation that belong to this class as outline by Christie, Jr. (1983) and the dictionary complier must include this information in the entry of the kin terms for the definition to be accurate. 


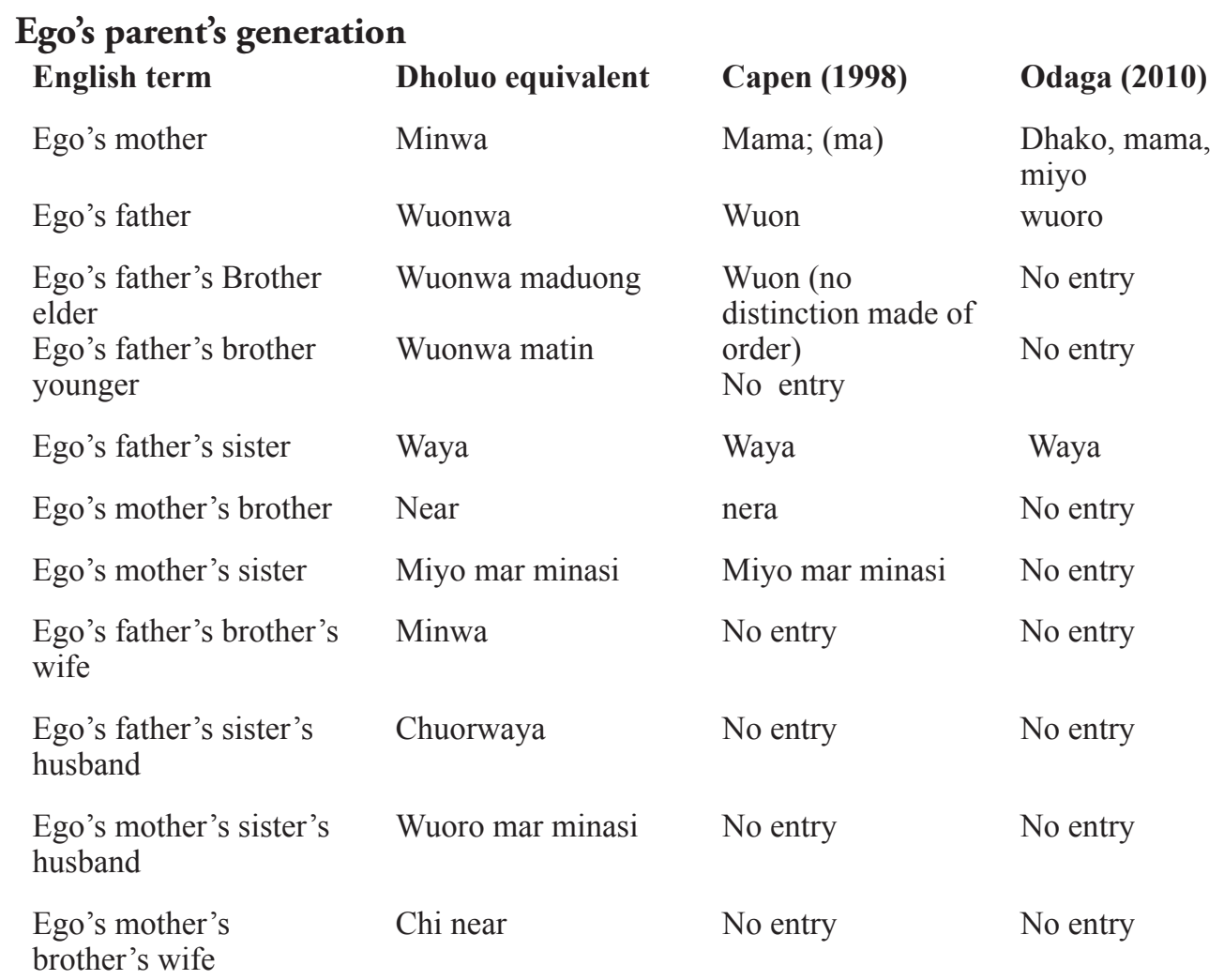

One of the central issues that English-Dholuo bilingual dictionaries have to contend with is the accurate and natural rendition of Dholuo equivalents of the English kinship terms in the ego's parent's generation. For example the English lexical item aunt refers to the sister of one's mother or father, and the wife of one's uncle. However, in Dholuo, the term aunt refers to a sister of one's father only who is referred to as waya. There are four entries: Ego's father's brother's wife, Ego's father's sister's husband, Ego's mother's sister's husband and Ego's mother's brother's wife that have not been captured by Capen (1998). Ego's father's brother and ego's father share the same lexeme wuoro or father and the main point of reference is Ego father and the father's brother are referred to as either old or younger depending on their exact relation to the father. A second significant feature is that Ego's father's step-brother is not distinguished from his biological brothers with whom he shares the same mother. The Sudanic kinship system of Dholuo has presented a challenge to translators who treated the Kinship terms as if they are Eskimo type that characterize English as seem in Odaga (2010) and Capen (1998). The lemma step-mother which has not been entered in Odaga (2010) and Capen (1998). Luo were predominantly polygamous and hence the reference wuod minwa son of my mother to distinguish biological brothers from wuod wuonwa son of my father, step brother or cousin. This relationship cannot be explained adequately without the step-mother terminology in the tree. The father's sisters are referred to as waya or aunt which distinguishes from the sisters of ego's mother who are referred to as minwa mothers since ego's mother, her sisters, step-sisters and cousins are all mothers who are distinguished from each other by their age as either older or younger mother in relation to ego's mother.

The English lemma 'uncle' is polysemous because it can refer to two different sets of relatives who are defined as 'the brother of either of ego's parents' or to designate one of two different but related classes of kinsmen, specifically the first is the husbands of ego's 'aunts' or more specifically of 'uncles by marriage' and secondly the brothers of grandparents, rather than of parents, in which case we may speak more precisely of 'great uncles'. Polysemy refers to instances where the same word may have a set of different meanings. In Dholuo the lemma uncle is restricted to the brother of one's mother and is lemmatized as 
near. Paternal uncles are referred to as fathers by ego.

According to Christie, Jr. (1983) Dholuo kin terms in Ego's parent's generation belong to the second class that completely neutralizes number in the suffixes, with the morphologically plural forms being used. Included in this class are wuon- 'father', min- 'mother', owad- 'brother' or 'male cousin', and nyamin'sister' or 'female cousin'.

\section{Possessive}

i) wuonwa

ii) wuonu

iii) wuongi

\section{gloss}

'our father'

'your father'

'their father'

All the Dholuo bilingual dictionaries under review have not taken into account the fact that possession is an inalienable aspect of Kinship terminology.

\section{Ego's grandparent's generation in Dholuo}

\begin{tabular}{|c|c|c|c|}
\hline English term & Dholuo equivalent & Capen (1998) & Odaga (2010) \\
\hline Ego's grandmother & Dana & Dayo & Dayo \\
\hline Ego's grandfather & Kwara & Kwaro & Kwaro \\
\hline Ego's great-grandfather & Kwara & No entry & No entry \\
\hline Ego's great-grandmother & Dana & No entry & No entry \\
\hline Ego's grandparents & Kwaro & No entry & $\begin{array}{l}\text { Jonyuolmeru, } \\
\text { Jonyuolwuoro }\end{array}$ \\
\hline Ego's grandfather's brother & Kwara & No entry & No entry \\
\hline Ego's grandfather's sister & Waya & No entry & No entry \\
\hline Ego's grandmother's brother & Kwaro & No entry & No entry \\
\hline Ego's grandmother's sister & Dayo & No entry & No entry \\
\hline $\begin{array}{l}\text { Ego's grandfather's Brother's } \\
\text { wife }\end{array}$ & Dayo & No entry & No entry \\
\hline $\begin{array}{l}\text { Ego's grandfather's sister's } \\
\text { husband }\end{array}$ & Kwara & No entry & No entry \\
\hline $\begin{array}{l}\text { Ego's grandmother's sister's } \\
\text { husband }\end{array}$ & Kwaro & No entry & No entry \\
\hline $\begin{array}{l}\text { Ego's grandmother's brother's } \\
\text { wife }\end{array}$ & Dayo & No entry & No entry \\
\hline
\end{tabular}

Christie, Jr. (1983) adds that Dholuo kin terms in Ego's grandparent's generation just like the parent's generation belong to the second class that completely neutralizes number in the suffixes, with the morphologically plural forms being used.

\begin{tabular}{llll}
\multicolumn{1}{l}{ Possessive } & gloss & \multicolumn{2}{c}{ Poss. Suffix } \\
i) kwara & 'my grandfather' & $-\mathrm{a}$ & $1^{\text {st }}$ person \\
ii) kwaru & 'your grandfather' & $-\mathrm{u}$ & $2^{\text {nd }}$ person \\
iii) kwargi 'their grandfather' & $-\mathrm{gi}$ & \multicolumn{2}{l}{$3^{\text {rd }}$ person }
\end{tabular}

There is need for the dictionary entry to capture the fact that possession is an integral part of kinship terms in Dholuo. 


\begin{tabular}{|c|c|c|c|}
\hline \multicolumn{4}{|c|}{ Ego's children's generation in Dholuo } \\
\hline English term & Dholuo equivalent & Capen (1998) & Odaga (2010) \\
\hline Ego's male child & Wuoda & Wuod & Wuod \\
\hline Ego's female child & Nyara & Nyar & $\begin{array}{l}\text { Nyar kaka inyalo } \\
\text { wacho ni nyar Otina }\end{array}$ \\
\hline Ego's brother's son & Wuod omera & Wuodowadwa & $\begin{array}{l}\text { Wuod } \\
\text { Owadu }\end{array}$ \\
\hline $\begin{array}{l}\text { Ego's brother's } \\
\text { daughter }\end{array}$ & Nyar nyaminwa & Nyaromera & Nyar owadu \\
\hline Ego's sister's son & Wuod Nyamera & $\begin{array}{l}\text { Woud nyamera } \\
\text { (okewa used by } \\
\text { male speaker) }\end{array}$ & $\begin{array}{l}\text { Nyathi nyameru } \\
\text { ma wuoi }\end{array}$ \\
\hline Ego's sister's daughter & Nyar nyanimwa & Nyarnyamera & Nyarnyaminu \\
\hline
\end{tabular}

A major short coming of the entries in both dictionaries under review is the fact that they do not include information of the Dholuo pronominal possession distinguishing three persons and two numbers, with markers as follows Advanced Tongue Root (+/-ATR) vowel quality, which is very critical in the kinship terminology of the Luo and are captured by the following suffixes according to Christie, Jr. (1983):

$\begin{array}{ll}\text { sg. } & \text { pI. } \\ \text { i) }-\mathrm{a} & - \text { wa } \\ \text { ii). -i } & - \text { u } \\ \text { iii) }- \text { e } & \text {-gi }\end{array}$

As can be seen, the words son and daughter are rendered as woud and nyar in both dictionaries and reference to possessions has been given by Odaga (2010) with regard to the third person while the Ego who is the central element in definition of kin terms has been ignored totally.

\begin{tabular}{|c|c|c|c|}
\hline \multicolumn{4}{|c|}{ Ego's Affinal Relations in Dholuo } \\
\hline English term & Dholuo equivalent & Capen (1998) & Odaga (2010) \\
\hline Ego's wife's father & Jaduong & Jaduong & No entry \\
\hline Ego's husband's father & Kwaro & Kwaro & No entry \\
\hline Ego's husband's mother & & Wounot & No entry \\
\hline Ego's wife's mother & Mara & Mara & No entry \\
\hline $\begin{array}{l}\text { Ego's wife's brother's } \\
\text { wife }\end{array}$ & Mara & No entry & No entry \\
\hline $\begin{array}{l}\text { Egos wife's sister's } \\
\text { husband }\end{array}$ & Sange & Sange & No entry \\
\hline Ego's brother's wife & Yuoro & Youro & No entry \\
\hline Ego's sister's husband & Or & Or & No entry \\
\hline
\end{tabular}

When an individual marries a man or woman s/he marries the family of their respective spouses together with all her close relatives. There are very specific duties and functions that each of the different extended relations play. Affinal kin are the individual who are related to ego by marriage. Direct affinity is the relationship between ego and his wife's relations by blood or between ego's wife and his relatives by blood. Collateral affinity is the relationship between the husband and the relations of his wife's relations. Some of the direct affinal relations are father-in-law, mother-in-law, Brother-in-law, sister-in-law etc. Comparing spoken English terms of sister-in-law and sister, sister-in-law is marked because the term 
has more structural coding compared to sister. Furthermore, sister-in-law may refer to Ego's spouse's sister or Ego's brother's wife. In turn, sister-in-law encodes a broader category of kin relations (with less distinction) as compared to sister which clearly specifies the conceptualized description of Ego's bloodrelated kin member who share same parent.

According to Christie, Jr. (1983), the fourth class of Dholuo kin terms has number neutralization in the second person only. This class contains only the noun mara 'mother-in-law (ego's wife's mother)', which has other morphological irregularities.

\section{Singular}

i) mara 'my mother-in-law'

ii) mara 'my mother-in-law'

iii) maru 'your mother-in -law'

iv) mar mare 'his mother-in-law'

v) maro mare ' his mother-in-law'

\section{Plural}

marwa 'our mother -in- law'

merewa 'our mothers -in-law'

mar margi'their mother-in-law'

mere margi 'their mothers-in-law'

This information on possession should be captured by the complier of a bilingual dictionary so as to communicate the accurate meanings of the words.

\section{Alternative Model of Kinship Terms Lemmatization}

The lemmatization of kin terms in the dictionaries that have been reviewed is rather unsatisfactory since the problems across the three languages can be summarized as follows:

i) There are a number of kin terms meanings that are missing in the dictionaries under review.

ii) There are a number of instances where terms are generalized in the target language while more specific terms would have been used.

iii) There are instances where specific terms are used instead of more general terms that capture all the aspects of meaning.

Bilingual dictionary users need entries which cover all the meanings they require, that is, meanings which provide them with the necessary information to make appropriate well-informed lexical choices (Scholfield, 1999). The ideal bilingual dictionary would anticipate every conceivable need of the prospective user. It would provide for each word or expression in the source language (SL) just the right target translation in the target language (TL) including most importantly; the one needed for the passage in hand (Hartmann, 1999).

The present paper suggests a model based on Wentzel and Muloiwa (1982) where each kin term is entered and the various sub-entries are entered under the main entry as shown below.

$\begin{array}{lll}\text { Brother-in-law ( main entry) } & \text { i) } & \text { ( sub-entry) Wife's brother } \\ & \text { ii) } & \text { ( sub-entry) Husband's brother } \\ & \text { iii) } \quad \text { ( sub-entry) Sister's husband etc. }\end{array}$

The above model yields better results and greater accuracy than the contrastive analysis model that was used in the compilation of the dictionaries under review. Grammatical information should also be included such as possession which is an integral part of the meaning of terms. All the meanings of the kinship terms and equivalents should also be provided. The model proposed suggests that there should be maximum discrimination of equivalent meaning so as to capture clearly the kinship term and enhance fluency in cross-cultural communication.

\section{Conclusion}


The treatment of kinship terms across the three languages which are quite unrelated are strikingly similar and the quality of entries seem rather below par. There are glaring gaps that need to be addressed in all the dictionaries that have been reviewed using the Wentzel and Muloiwa (1982) model. This can be attributed to a number of factors one of which can be the fact that translators and linguistics have not taken up the tack of lexicography in the said languages and those who have been doing the work have not treated the task as per expectation.

\section{References}

Baker, M. (1992/2006), In Other Words: A Coursebook on Translation, 2nd edn. London and New York, Routledge.

Bosire, K. M. \& Machogu, G. K. (2009). Authoritative Ekegusii dictionary. Mombasa: Ekegusii

Encyclopedia Project.

Capen, C. A. (1998). Bilingual Dholuo-English dictionary. Tuscon, Arizona: C. A Capen.

Christie, Jr., W. M. (1983). A note on the kinship system of Kenya Luo. Studies in African

Linguistics, 14(3).

Greenberg, J. (1970). The languages of Africa. Bloomington: Indiana University Press.

Hartmann, R (1999) Lexical Reference Books- what are the issues? National Jouyrnal of Lexicography12(1):5-12

Kabaji, E. (2005). The construction of gender roles through the narrative process of the African folktale: A case study of the Maragoli folktale (Unpublished doctoral thesis), University of South Africa, South Africa.

Guthrie, M. (1948). The classification of Bantu languages. London: Oxford University Press.

Gwako, E. L. (2014). Maragoli and Gusii farmers in Kenya: Strong collective action and high prosocial punishment. In J. Ensminger \& J. Henrich (Eds.), Experimenting with social norms fairness and punishment: In cross-cultural perspective. New York: Russell Sage Foundation.

McHenry, R. (Ed.). (1992). New encyclopaedia britannica (Vol. 4). Chicago: Encyclopaedia Britannica Inc.

Murdock, George Peter (1949). Social Structure. New York: The MacMillan Company.

Ndanyi, J. O. (2005). English-Lulogooli translation dictionary. Nairobi: Ndanyi Enterprises.

Nida, E. A. and Taber, C. (1982): The Theory and Practice of Translation, E.J. Brill, Leiden.

Odaga, B. A. (2010). English-Dholuo dictionary. Kisumu: Lake Publishers Ltd.

Prinsloo, D. J. \& de Schryver, G. M. (2002). Reversing an African-language Lexicon: The Northern Sotho terminology and orthography No. 4 as a Case in Point. South African Journal of African Languages, 22(2), 161-185.

Scholfield, P. (1999). Dictionary use in reception. International Journal of Lexicography, 12(1), 13-34.

Stone, L. (2000). Kinship and gender: An introduction (2nd ed.). Colorado: Westview.

Wentzel, P. J. \& Muloiwa, T, W. (1982). Improved trilingual dictionary: Venda-Afrikaans-

English. Pretoria: University of South Africa.

\section{About the Authors}

Dr. Joyce Wangia and Gerry Ayieko are both faculty, Department of English and Linguistics, Kenyatta University. 